\title{
ОСЛОЖНЕНИЯ ГЕСТАЦИИ В ЗАВИСИМОСТИ ОТ ИНДЕКСА МАССЫ ТЕЛА
}

\author{
Абусуева 3.А., Омарпашаева М.И., Магомедова М.А., Хашаева Т.Х-М., Мухтарова М.М.
}

ФГБОУ ВО «Дагестанский государственный медицинский университет», Махачкала

ЦЕЛЬ: определить особенности течения и возможные осложнения беременности и родов у женщин с различными степенями ожирения.

МАТЕРИАЛЫ И МЕТОДЫ: исследование носило характер ретроспективного. Проанализировано 100 историй родов женщин с различными степенями ожирения, находившихся в отделениях ГБУ РД «Махачкалинский родильный дом №2» в 2019 году.

РЕЗУЛЬТАТЫ: осложнения данной беременности наблюдались в 82\% случаев. Ранний токсикоз наблюдался у каждой третьей женщины с ожирением (36\%). Преэклампсия наблюдалась в 62,5\% (45 женщин) при 1 степени ожирения, в 72,2\% (13женщин) при 2 степени ожирения, и в 100\% случаев при ожирении 3 степени. Осложненное течение родов зарегистрировано у 48\% родивших: при 1 степени ожирения у 44,4\%, при 2 - у 55,5\%, при 3 y $60 \%$.

ВЫводы: представленные выше данные свидетельствуют об увеличении частоты встречаемости осложнений гестации с увеличением ИМТ.

Ожирение - наиболее распространенная форма нарушения обмена веществ, особенно в экономически развитых странах, где частота данной патологии не имеет тенденции к снижению, и каждая четвертая беременная страдает избыточной массой тела и различными степенями ожирения.

Нарушения жирового обмена отрицательно сказываются на функциональном состоянии различных органов и систем организма беременной женщины, повышая риск развития осложнений гестации, родов и послеродового периода, а также увеличивают частоту перинатальной заболеваемости и смертности новорожденных.

С целью определить и оценить особенности течения и возможные осложнения беременности у женщин с различными степенями ожирения нами проанализировано 100 историй родов женщин с ожирением. Сформировано три группы: 1 группа — пациентки с ИМТ до беременности 30-34,9 кг/м² и ожирением 1 степени - 72 женщины (72\%), 2 группа — пациентки с ИМТ 35-39,9 кг/м² и ожирением 2 степени - 18 женщин (18\%), 3 группа пациентки с ИМТ более $40 \mathrm{kr} / \mathrm{M}^{2}$ и ожирением 3 степени - 10 женщин (10\%). Средний возраст составил 28,4+-0,7 лет (95\% ДИ: 24,6-30,1), 29,8+-0,3 лет (95\% ДИ: 26,2-29,2), 29,1+-0,5 лет (95\% ДИ: 25,9-31,1) соответственно по группам без статистически значимых различий. Количество первородящих в 1 группе составило 48,6\% (35 женщин), во 2 группе 55,5\% (10 женщин), в 3 группе - 60\% (6 женщин). Из 100 проанализированных случаев экстрагенитальная патология встречалась у $80 \%$ пациенток. Наиболее часто у данной категории встречалась гипертоническая болезнь в $32 \%$ случаев, заболевания мочевыделительной системы в $35 \%$ случаев (хронический пиелонефрит), а также заболевания Лор-органов - в 18\% случаев (хронический тонзиллит).

Гинекологический анамнез отягощен у $75 \%$ родивших. Наиболее часто встречались воспалительные заболевания органов репродуктивной системы в анамнезе (1гр. - 33,3\%, 2 гр. - 38,8\%, 3 гр. - 20\%), нарушения регулярности менструального цикла (1 гр. - 27,7, 2 гр. - 22,2\%, 3 гр. - 10\%), невынашивание беременности (1 гр. - 26,3\%, 2 гр. - 16,7\%, 3 гр. - 20\%), бесплодие (1 гр. - 33,3\%, 2 гр. - 38,8\%, 3 гр. - 30\%).

Осложнения данной беременности наблюдались в $82 \%$ случаев. Ранний токсикоз наблюдался у каждой третьей женщины с ожирением (36\%). Угроза прерывания в первой группе встречалась в 52,7\% (38 женщин), во второй группе в 66,7\% (12 женщин), в третьей группе в 70\% случаев (7 женщин). Железодефицитная анемия обнаружена в 55,5\% (40 женщин), 66,7\% (12 женщин), 60\% (6 женщин) соответственно по группам. Преэклампсия наблюдалась в 62,5\% (45 женщин) при 1 степени ожирения, в 72,2\% (13 женщин) при 2 степени ожирения, и в 100\% случаев при ожирении 3 степени.

Роды произошли в срок у 84,7\% женщин 1 группы, у 83,3\% - во 2 группе, у 90\% - в 3 группе. Перенашивание беременности наблюдалось у 11,1\% в 1 группе, у 5,5\% во второй группе и у $10 \%$ в третьей. Преждевременные роды у 4,2\% женщин в 1 группе и у 11,1\% женщин во второй группе. Осложненное течение родов зарегистрировано у $48 \%$ родивших: при 1 степени ожирения у $44,4 \%$, при 2 - у 55,5\%, при 3 - у $60 \%$. Аномалии родовой деятельности обнаружены у $11,1 \%, 16,6 \%$ и $30 \%$ женщин соответственно.

Таким образом, ожирение, частота которого имеет достоверную тенденцию к увеличению, является отрицательным преморбидным фоном для развития беременности и течения родов. Представленные выше данные свидетельствуют о увеличении частоты встречаемости осложнений гестации с увеличением ИМТ. Все это позволяет относить женщин с ожирением к группе риска по развитию перинатальной заболеваемости. 